\title{
Response of a Scarlet Macaw Ara macao population to conservation practices in Costa Rica
}

\author{
CHRISTOPHER VAUGHAN, NICOLE M. NEMETH, JOHN CARY and \\ STANLEY TEMPLE
}

\section{Summary}

The Central Pacific Conservation Area contains one of Costa Rica's two viable, but threatened Scarlet Macaw Ara macao populations. For 14 years (1990-2003), we monitored the size of this population. Non-linear models fitted to 1990-1994 observations revealed seasonal and longterm changes in population size. The peak of annual population size occurred in August, with a cyclic range of about 90 birds between the lowest and highest points of the annual cycle. The best model also revealed a decline in population size of approximately eight birds counted per year or $4 \%$ of the total population per year (1990-1994). Young-to-adult ratios calculated for the month of August during this study fluctuated around a baseline that averaged 6.1\% a year (1990-2003). These ratios exceeded 8\% for three different years (1995, 1996 and 2000). All three of these "good" recruitment years occurred after management began, and two of them were associated with zealous anti-poaching efforts that ultimately could not be sustained. After intensive management practices began in 1995, the August counts increased by about 37 individuals in two years (1995-1996) to an average 243 individuals, which remained almost constant up to 2003. Management practices included creation of a local conservation organization that coordinated environmental education, artificial nest construction, networking among stakeholders and with governmental authorities, and artificial and natural nest protection. Although Scarlet Macaw conservation efforts have been inconsistent since 1997, our study demonstrates that collaborative conservation by local stakeholders increased the population of this threatened species in 1995-1996, and from 1996 to present the population has sustained itself.

\section{Introduction}

At least $44(30 \%)$ of the 146 species of New World parrots are threatened, and the remaining 102 species are experiencing declines in numbers due to habitat destruction, consumption, and exploitation for the pet trade (Collar and Juniper 1992, Collar 200o). The Association for Parrot Conservation (APC) and The International Union for the Conservation of Nature (IUCN) Parrot Conservation Action Plan recommend monitoring psittacine populations (Snyder et al. 1987, 2000, Beissinger et al. 1994). However, long-term monitoring studies are rare for psittacine populations because they are logistically and financially difficult to achieve.

Scarlet Macaw Ara macao is classified as threatened (Appendix I) under the Convention on International Trade in Endangered Species (CITES), and numbers have declined within their present range (Wiedenfeld 1994, Iñigo-Elías 1996). In Costa Rica, the two remaining viable Scarlet Macaw populations have been estimated at 700 individuals in the Osa Conservation Area, and 330-400 individuals in the Central 
Pacific Conservation Area (Stiles and Skutch 1989). Here, we present results from an intensive monitoring study (1990-2003) and a conservation management experiment with monitoring (1995-2003), and we assess the impact of conservation management activities on the Central Pacific Scarlet Macaw population.

\section{Study area and population}

The Scarlet Macaw population that we studied occupied a $560 \mathrm{~km}^{2}$ mosaic of natural forest in the Central Pacific Conservation Area, Costa Rica. The area included altered habitats (cattle pasture, annual or perennial crops, and early stage successional forest) and several hundred human dwellings (Fallas 1995, Marineros and Vaughan 1995). The 5,500 ha Carara National Park $\left(9^{\circ} 40^{\prime} \mathrm{N}, 84^{\circ} 40^{\prime} \mathrm{W}\right)$ formed the core of the Scarlet Macaw's range. Other protected areas included Turrubares Protected Zone $\left(33 \mathrm{~km}^{2}\right)$, Guacilillo Mangrove Reserve $\left(11 \mathrm{~km}^{2}\right)$ and Punta Leona Private Wildlife Refuge $\left(0.3 \mathrm{~km}^{2}\right.$ ) (Figure 1a). Four life zones in the study area included tropical dry forest to humid forest transition, tropical humid forest, premontane forest and tropical wet forest (Tosi 1969).

A portion of the Scarlet Macaw population moves daily between nocturnal roosting sites in Guacilillo Mangrove Reserve and feeding and nesting areas in other parts of the range (Marineros and Vaughan 1995). Macaws in the area fly as single birds, pairs, triplets (parents with one offspring) and quadruplets (parents with two offspring) along three flyways (North, Central and South) (Figure $\mathrm{Ib}$ ). Biological research on the natural history of this population has focused on diet (Marineros 1993, Marineros and Vaughan 1995, Nemeth and Vaughan 2004, Vaughan et al. in press), nesting (Marineros and Vaughan 1995, Vaughan et al. 2003a) and chick movements and behaviour (Myers and Vaughan 2004), while social research has focused on ecotourism (Vaughan 1999), environmental education (Vaughan et al. 2003b) and local conservation strategies (Vaughan 2002).

\section{Methods}

\section{Scarlet Macaw observations}

Between March 1990 and August 2003, flocks of Scarlet Macaw were counted during daily flights to and from their nocturnal roosting area (05hoo-07hoo and 16hoo18hoo, respectively). Between two and 51 counts per month were made between March 1990 and December 1994. Beginning in 1995, counts took place exclusively in August. Count data included date and time of observation, flyway (North, Central or South), flock size (number of birds per group observed) and composition of flocks (either single, pair, trio or quartet). A total of 939 counts were made from 1990-2003 by 14 different observers trained by the senior author, using a standardized data sheet. This included 555 counts for 56 contiguous months between March 1990 and October 1994 during the intensive monitoring phase of this study. A total of 171 August counts were made from 1990 to 2003, with no counts during 1998 and 2001.

\section{Seasonal and annual variation 1990-1994}

From 1990 to 1994, flocks of macaws were counted from the point referred to as "ricefield". By 1994, vegetation obscured a portion of the South flyway, so subsequent counts were made from a point referred to as "bridge" (Figure 1b). In 1995 and 1999, 
we made simultaneous counts from the rice-field and the bridge to establish the following conversion factor: Bridge $=80.85+0.92 \times$ Rice $\left(R^{2}=0.723\right)$ (Figure 2). We applied this conversion to the rice-field counts prior to 1995 so that they were comparable to all subsequent counts from the bridge. We used the uncorrected rice-field counts from 1990 to 1994 to describe seasonal and annual variation in macaw numbers. Counts were summarized as monthly averages of the daily observations.

Within-year fluctuations during 1990-1994 were modelled as cosine curves (Bulmer 1974) with additional terms for linear and quadratic effects of time. Six

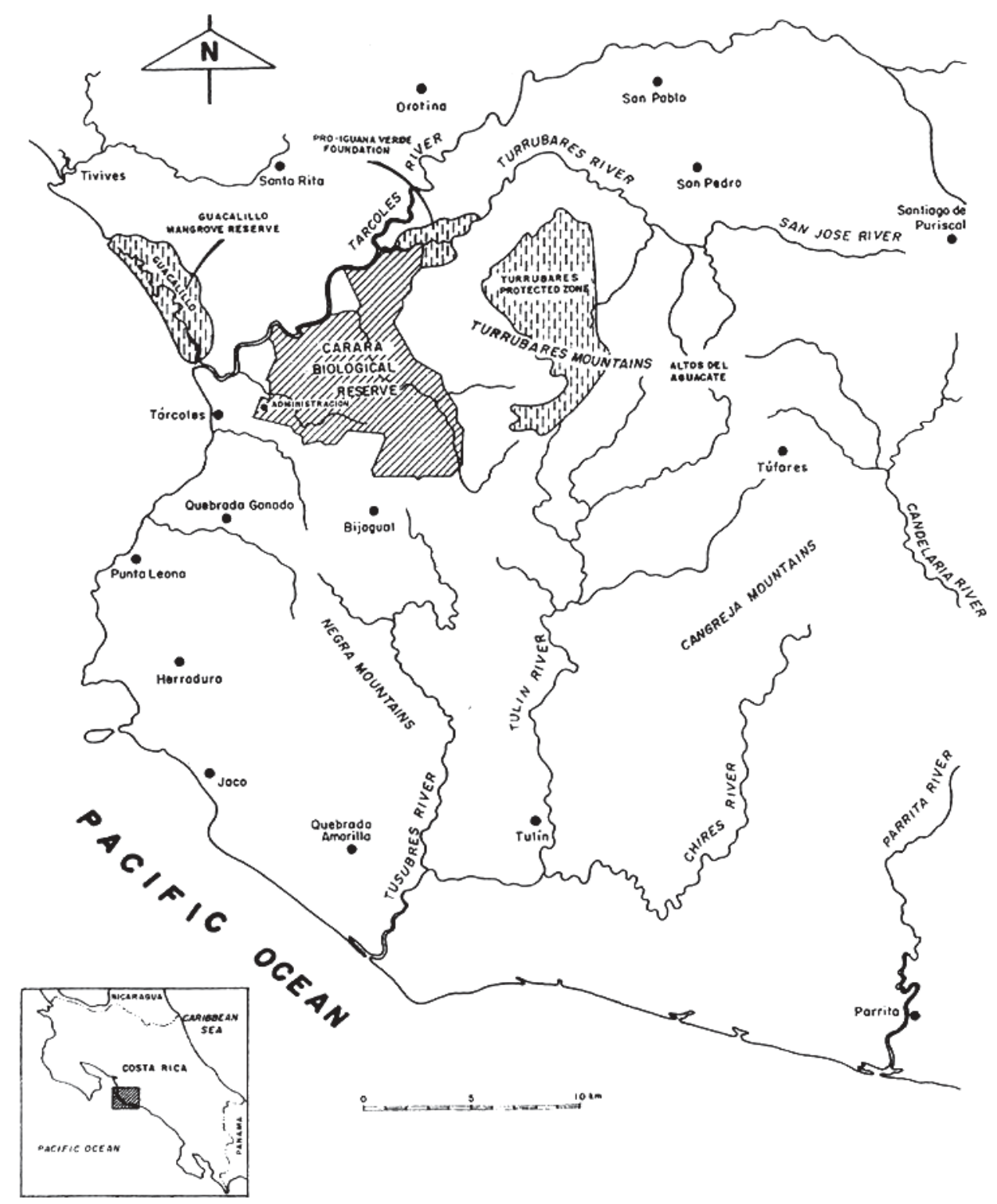

Figure 1. (a) Study area in Central Pacific Costa Rica. 


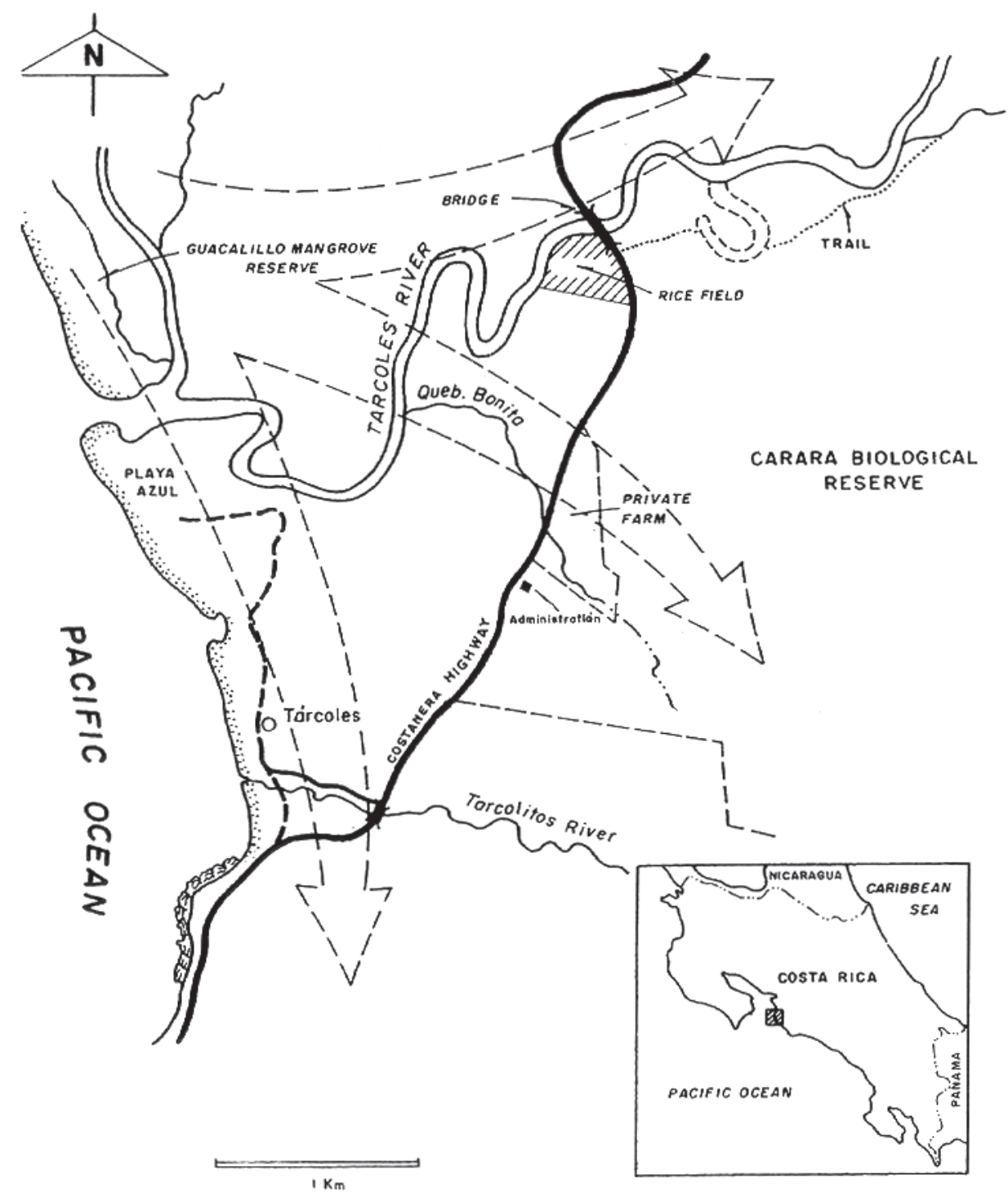

Figure 1. (b) Flyways used by the Scarlet Macaw during daily movements, Central Pacific Conservation Area, Costa Rica.

models were used to describe seasonal and annual variation for counts taken continuously from 1990-1994 (Table 1). Mallow's C p $_{\mathrm{p}}$ statistic (Draper and Smith 1998) guided the interpretation of the model of best fit to the observations Criterion (Anderson and Burnham 2001).

\section{Effects of management since 1995}

A regional Scarlet Macaw workshop held in October 1994 developed a macaw conservation strategy to minimize macaw chick poaching, enhance habitat for the species and 


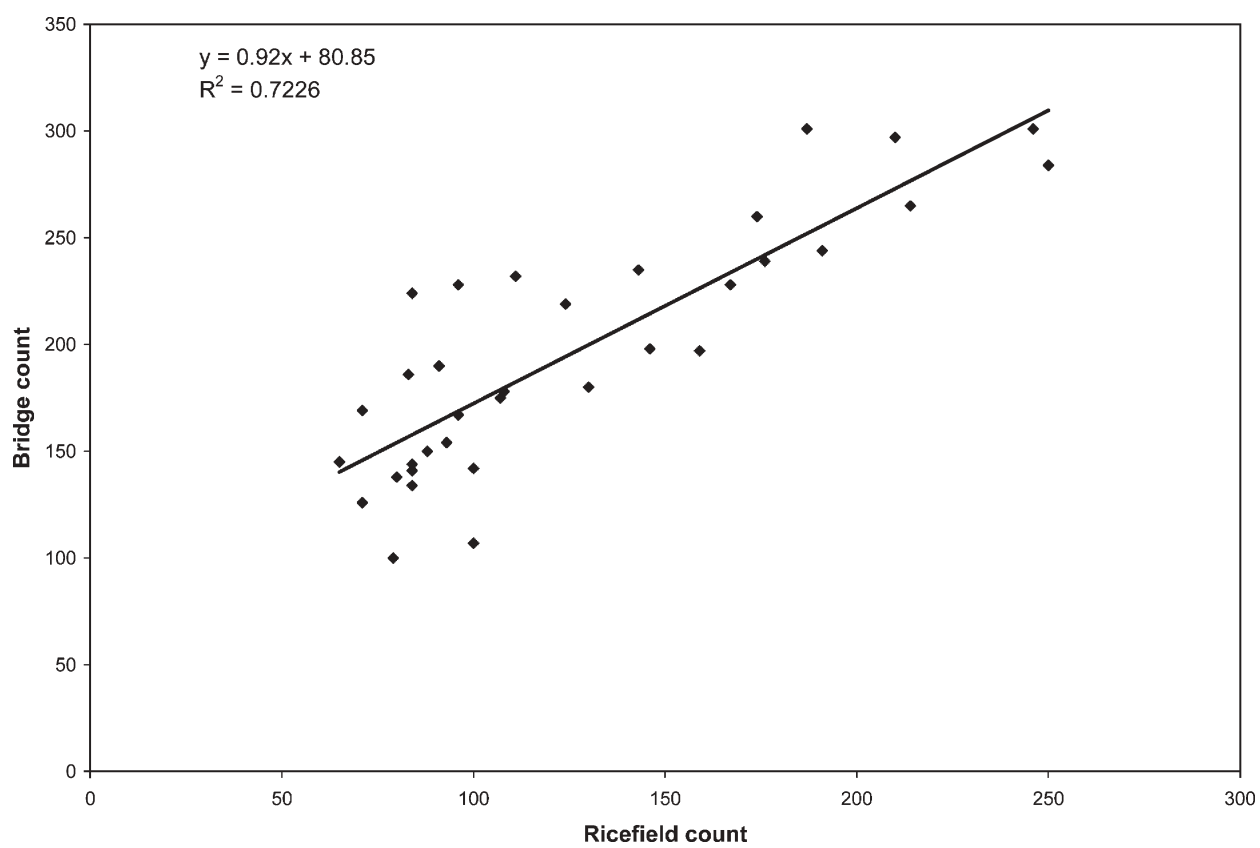

Figure 2. Comparison of simultaneous Scarlet Macaw counts from rice-field and bridge locations, Central Pacific Conservation Area, Costa Rica.

Table 1. Multiple models for monthly mean Scarlet Macaw counts (1990-1994) ( $\mathrm{n}=555$ counts).

\begin{tabular}{llrlrrr}
\hline Model idea & Model & $\mathrm{P}$ & RSS & $R^{2} \operatorname{corr}$ & $s^{2}$ & \multicolumn{1}{c}{$C_{\mathrm{p}}$} \\
\hline Constant & $y=b_{0}$ & 1 & 84,922 & 0 & 1572.63 & 122.19 \\
Linear trend & $\mathrm{y}=b_{0}+b_{1} * \mathrm{t}$ & 2 & 78,878 & 0.07 & 1488.26 & 111.93 \\
Annual cycle & $\mathrm{Y}=b_{0}+b_{2} * \cos \left(2 \pi * b_{3} *\left(t-b_{4}\right)\right)$ & 4 & 31,322 & 0.63 & 614.16 & 19.51 \\
Linear trend + cycle & $\mathrm{Y}=b_{0}+b_{1} * t+b_{2} * \cos \left(2 * \pi * b_{3} *\left(t-b_{4}\right)\right)$ & 5 & 24,660 & 0.71 & 493.20 & 8.00 \\
Quadratic trend + cycle & $\mathrm{Y}=b_{0}+b_{1} * t+b_{2} * \cos \left(2 * \pi * b_{3} *\left(t-b_{4}\right)\right)+6$ & 24,656 & 0.71 & 503.18 & 9.99 \\
& $\quad b_{5} * t^{2}$ & & & & & \\
Cubic trend + cycle & $\mathrm{Y}=b_{0}+b_{1} * t+b_{2} * \cos \left(2 * \pi * b_{3} *\left(t-b_{4}\right)\right)+7$ & 24,652 & 0.71 & 513.58 & 11.98 \\
& $b_{5} * t^{2}+b_{6} * t^{3}$ & & & & & \\
\hline
\end{tabular}

$\mathrm{P}$, number of parameters in model; RSS, residual sum of squares of deviation between model and observations; $R^{2}$ corr, fraction of variation explained; $s^{2}$, residual variance; $C_{\mathrm{p}}$, Mallows $C_{\mathrm{p}}$ statistic (Draper and $\mathrm{Smith}$ 1998).

educate the local community. A legally constituted local Scarlet Macaw conservation organization (Association for Parrot Protection, or LAPPA) was formed to coordinate all macaw conservation activities with stakeholders (ranchers, park officials, scientists, local community members and ecotourism managers). Activities included environmental education, meetings with stakeholders, promoting economic incentives in the region based on macaws, artificial nest-box construction, and protection of natural and artificial nests (Vaughan 2002).

Average August counts and yearly young-to-adult ratios in the counts were used to compare the status of the macaws before (1990-1994) and after (1995-2003) outreach 
and management activities were initiated. The yearly young-to-adult ratios were derived from the August count data with trios and quartets considered an adult pair with one or two offspring (Munn 1992, Toyne and Flanagan 1997, Myers and Vaughan 2004), and a flock of two considered a pair of adult birds. We calculated the ratio of young to adults as: young/adult $=(2 \mathrm{Q}+\mathrm{T}) /(2 \mathrm{Q}+2 \mathrm{~T}+2 \mathrm{P}+1 \mathrm{~S})$, where $\mathrm{Q}$ is the number of quartets, $\mathrm{T}$ is the number of trios, $\mathrm{P}$ is the number of pairs and $\mathrm{S}$ is the number of single birds. We used $t$-tests to compare changes in counts and young-to adult ratios before and after initiation of management. Alternative explanations for response to management were evaluated via Mallow's $C_{p}$ statistic (Draper and Smith 1998).

\section{Results}

\section{Seasonal and annual variation 1990-1994}

Of the six competing models describing variation in counts from 1990 to 1994, the fourth model, which incorporated a linear trend plus cyclic variation, best fitted the 56 monthly averages, as indicated by the $\mathrm{C}_{\mathrm{p}}$ statistic (Table 1 ). The linear trend estimates a loss of 8.2 birds per year from 1990 to 1994 (Figure 3).

The coefficients of the cosine cycle quantify the annual oscillation derived from count observations. The frequency of oscillation is 0.995 , which is consistent with an

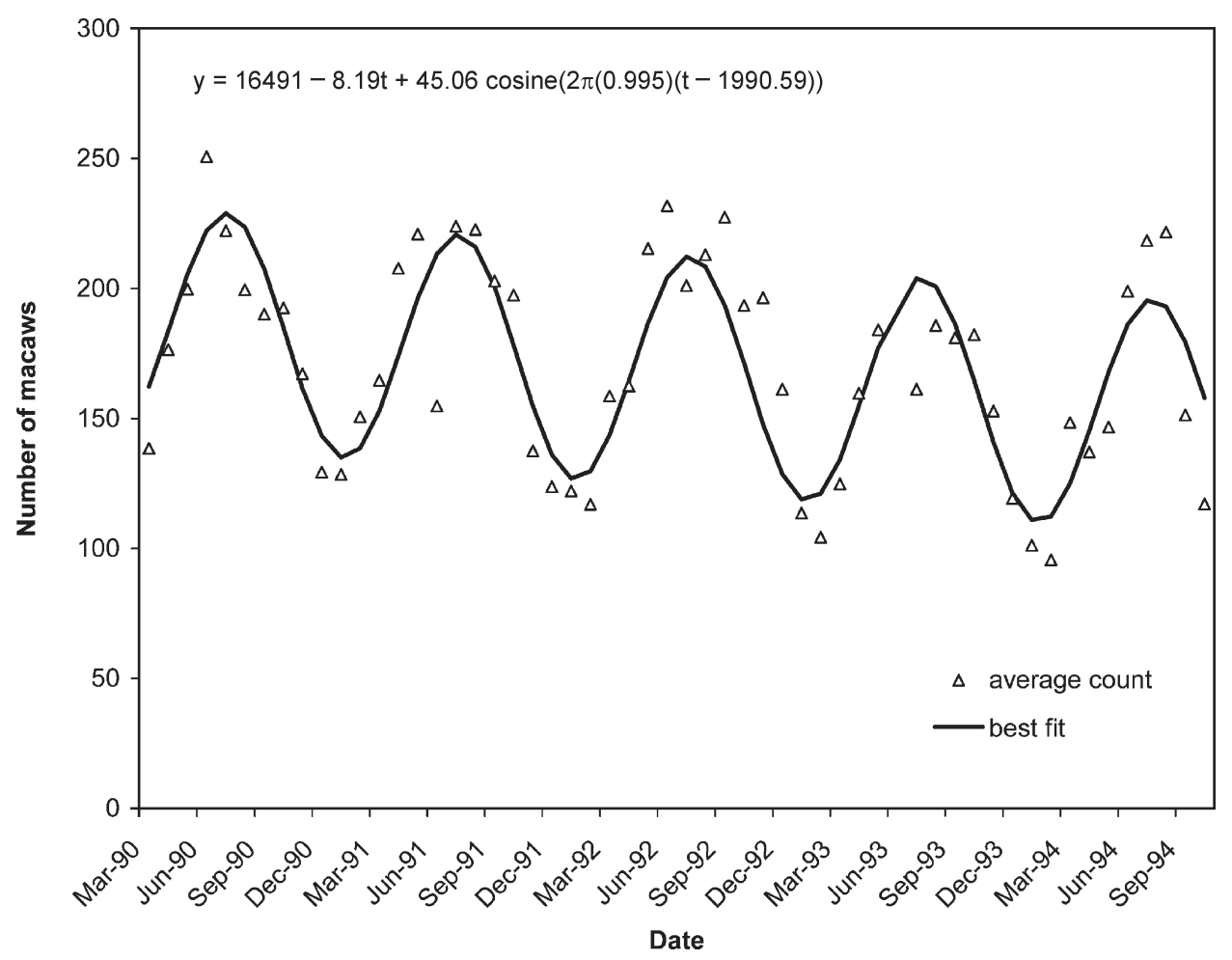

Figure 3. Model of best fit for average monthly counts of Scarlet Macaw population, Central Pacific Conservation Area, Costa Rica (1990-1994) ( $n=550$ counts). 
annual cycle. The amplitude of oscillation is 45.0 birds, so that the range of cyclic variation is approximately 90 birds. Phase shift of cyclic seasonal change within a year is used to locate the start of the observed cycle relative to the zero point of the time series. The peak of each annual cycle occurred near or on 4 August of each year (Figure 3).

\section{Effects of management since 1995}

Four competing models were used to describe population trajectories in response to management (Table 2). The no-change scenario is eliminated from possibility because of the $\mathrm{C}_{\mathrm{p}}$ criterion, but the remaining three models are indistinguishable from each other. Macaw numbers observed in August counts increased following management (Figure 4), but a clear differentiation among the three change hypotheses is not revealed by the data.

\section{August young-to-adult ratios}

We attempted to fit models (Table 2) to the young-to-adult ratios. None of the change hypotheses was superior to the no-change model. Thus, it appeared that an average of $6.1 \%$ of the adult birds were "recruited" annually to the population. However, after management began, markedly higher recruitment occurred with ratios in excess of $8.0 \%$ in 1995, 1996 and 2000 (Figure 5). The frequency of years with high recruitment before management (o of 5 years) differed from those observed following management ( 3 of 7 years), but not significantly $\left(\chi^{2}=2086, P=0.09\right)$. All three of the "high" recruitment years occurred following intensive management efforts, and two of these years were associated with zealous anti-poaching efforts that would have been very difficult to sustain over the long term (Figure 5).

\section{Discussion}

\section{Seasonal and annual variation 1990-1994}

The APC and IUCN Parrot Conservation Action Plan recommend monitoring psittacine populations to determine long-term population trends (Snyder et al. 1987, 2000, Beissinger et al. 1994). However, cyclic or seasonal count variation has been

Table 2. Multiple models for mean August Scarlet Macaw counts (1990-2003) ( $\mathrm{n}=171$ counts).

\begin{tabular}{llllllr}
\hline Model idea & Model & $\mathrm{P}$ & $\mathrm{RSS}$ & $R^{2}$ corr & $s^{2}$ & $C_{\mathrm{p}}$ \\
\hline No change between years & $y=b_{0}$ & 1 & 5100.7 & 0 & 463.70 & 12.32 \\
Linear trend & $y=b_{0}+b_{1} t$ & 2 & 2562.8 & 0.5 & 256.28 & 4.21 \\
Quadratic trend & $y=b_{0}+b_{1} t+b_{2} t^{2}$ & 3 & 2432.1 & 0.52 & 270.23 & 5.69 \\
Switch to new equilibrium & $y=b_{1}+\left(b_{2}-b_{1}\right) \mathrm{e}^{(t-b 3) / b 4 /}$ & 4 & 2008.5 & 0.61 & 251.06 & 6.00 \\
& $\left(1+\mathrm{e}^{(t-b 3) / b 4}\right)$ & & & & & \\
\hline
\end{tabular}

$\mathrm{P}$, number of parameters in model; RSS, residual sum of squares of deviation between model and observations; $R^{2}$ corr, fraction of variation explained; $s^{2}$, residual variance; $C_{\mathrm{p}}$, Mallows $C_{\mathrm{p}}$ statistic (Draper and $\mathrm{Smith}$ 1998).

$b_{1}$, the coefficient for the first equilibrium; $b_{2}$, the coefficient for the second equilibrium; $b_{3}$, the coefficient which indicates the time when the equilibrium switched; $b_{4}$, the shape of the switch. 


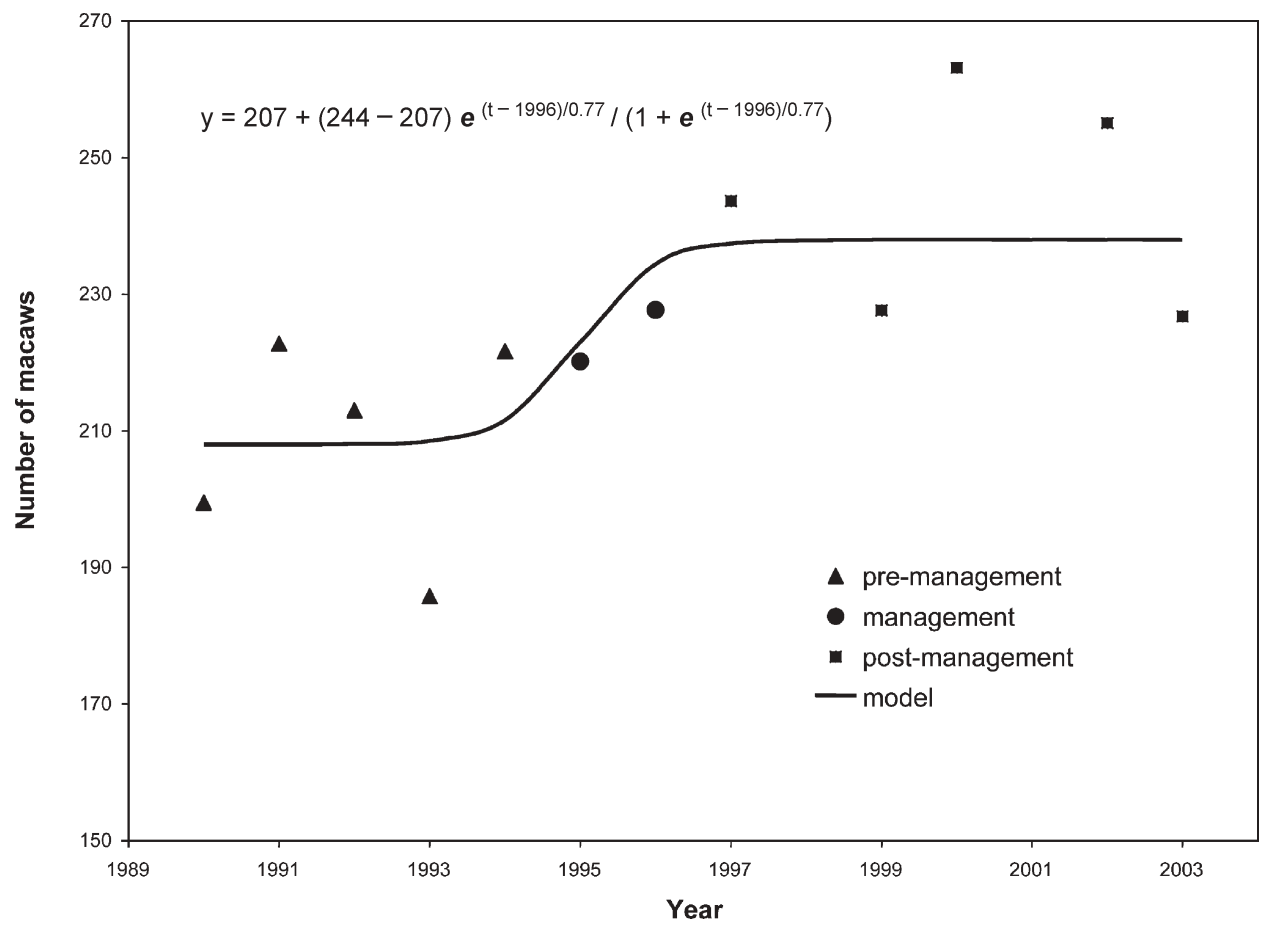

Figure 4. Model of best fit for average August counts of Scarlet Macaws population, Central Pacific Conservation Area, Costa Rica (1990-2003) ( $n=171$ counts).

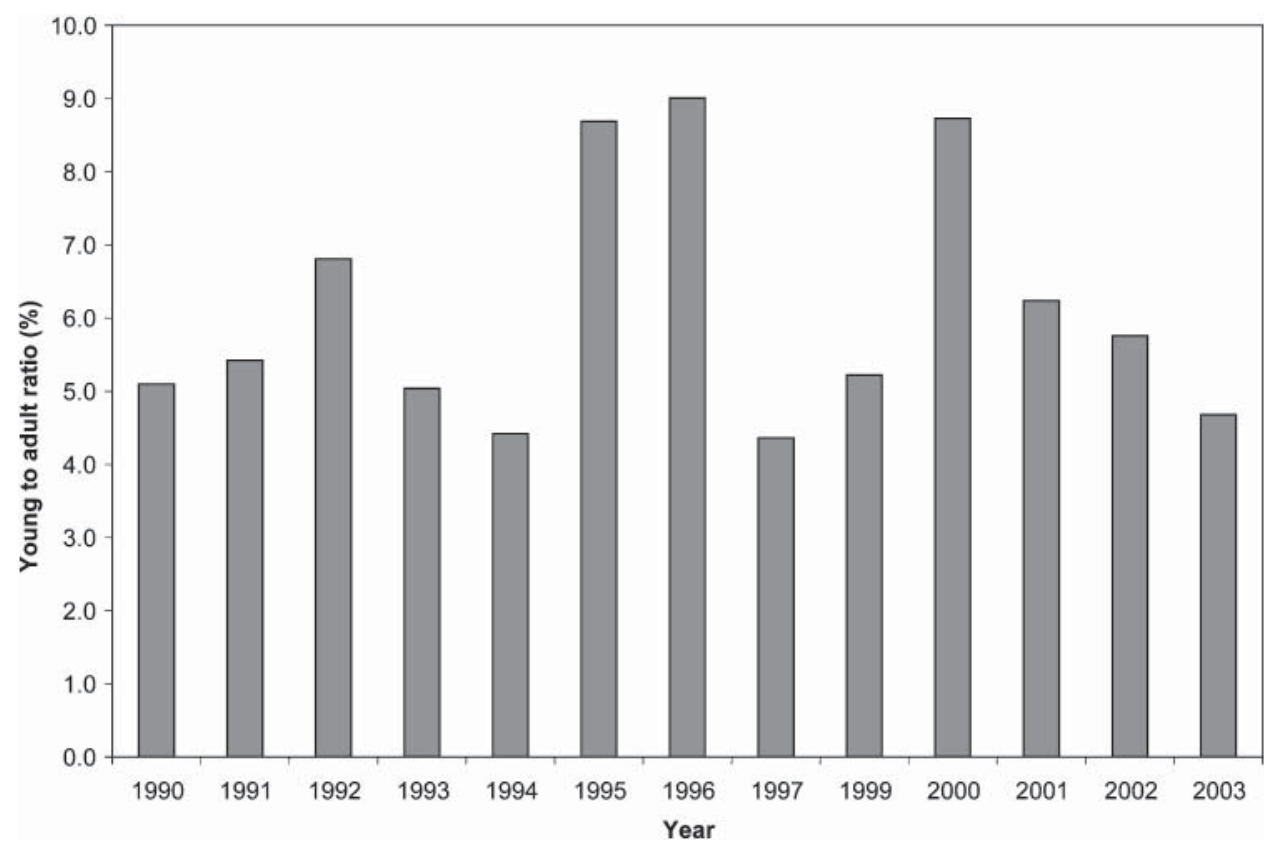

Figure 5. Average young-to-adult ratio based on August counts in Scarlet Macaw population, Central Pacific Conservation Area, Costa Rica (1990-2003) ( $n=171$ counts). 
documented in several macaw species: A. manilata (Bonadie and Bacon 200o), A. ararauna, A. chloroptera and $A$. macao (Renton 2002), as well as other psittacines (Chapman et al. 1989). Though research settings and other circumstances are highly varied, there is a need to standardize methods of population assessment to interpret and strategize for conservation practices.

Seasonal changes in breeding behaviour, availability of fruits and other foods, and physical environment may contribute to seasonal count variation. Our counts varied seasonally, with the highest monthly average counts and young-to-adult ratios in August when adult Scarlet Macaw pairs with fledglings rejoined the roosting flock. In our study, the lowest counts were from January to March when nesting pairs did not make daily migrations to the mangrove roost, but remained at nest-sites to defend nests and care for young (Marineros and Vaughan 1995, Vaughan 2002).

The best-fit model (Figure 3, Table I) shows a loss of 8 macaws per year (19901994) from a closed population of an average of 160 individuals, representing a $5 \%$ annual adult decline. Local stakeholders considered poaching of chicks from the nest the most serious threat to the Central Pacific Scarlet Macaw population (Vaughan 2002). Of 56 nests in the region, $87 \%$ (48) were considered at medium or high poaching risk (Vaughan et al. 2003 b). Researchers estimated an average of $30 \%$ chick poaching rate in 23 Neotropical parrot studies; four had estimates of over $70 \%$ poaching rate (Wright et al. 2001).

\section{Effects of management 1995-present}

Although counts of macaws in August definitely changed over 1990-2003, the linear trend model is questionable because it conflicts with the 1990-1994 results (Figure 3, Table 1). The quadratic change model is also questionable, not because of the early decrease but because the increase in population size was not sustained after 1996. The significant switch to a new equilibrium model is perhaps the most plausible explanation, because it is based on historical knowledge of the intensive management efforts during the 1995-1996 periods.

The years of highest young-to-adult ratios (1995, 1996 and 2000) were likely years when many young fledged from their nests and were recruited into the population (Figure 5). These years also coincided with the maximum number of young observed (27 young on 18 August 1995, 30 young on 21 August 1996 and 30 young on 8 August 2000). Management was intense during 1995-1996, which might explain the population increase of an estimated 37 birds. Management included raids of suspected poachers' homes by park guards and a local judge, confiscation of poached chicks and tree-climbing gear, arrests of poachers, newspaper articles denouncing specific macaw poachers (La Nación 1995), artificial nest-box construction and placement, and active nest protection (Vaughan 2002). Additional management activities included environmental education programmes (Vaughan et al. 2003a) and extensive networking among stakeholders (Vaughan 2002). One renowned poacher was incarcerated for an unrelated crime, possibly increasing the number of chicks recruited into the population during the time he was in jail. Unfortunately, in more recent years, poaching was lessened from a felony to a misdemeanour in Costa Rica, punishment fines were reduced, and fewer Carara National Park guards were available for protection during the critical nesting season. 


\section{Importance of ecotourism in Central Pacific Costa Rica}

The Central Pacific Scarlet Macaw population is highly significant to the ecotourism business. Over 40,000 foreign tourists spent US\$6 million in 1994 during visits to Carara National Park; most came to see Scarlet Macaws (Damon and Vaughan 1995). However, in 1994, over 90\% of money spent by tourists did not benefit local communities (Marineros 1993, Marineros and Vaughan 1995, Vaughan 1999). This has changed in recent years with the burgeoning tourism field in the Central Pacific, which now employs more adult Costa Ricans than any other industry. It is to be hoped that chick poaching will cease when local communities feel that economic gains are greater from macaw conservation than from poaching (Ferraro and Kramer 1997, Vaughan 1999).

\section{Sustainability of the Central Pacific Scarlet Macaw population}

At present, the Central Pacific Scarlet Macaw population is self-sustained (Figures 3, 4), even with heavy poaching pressure. Once successfully fledged from the nest, macaws appear to have a high survival rate (Myers and Vaughan 2004). It is fortunate that adult macaws in Central Pacific Costa Rica are not under the same hunting pressure as they are in many South American countries (Thomsen 1995). We recommend that protection measures become more stringent, vigilance be kept over known poachers, artificial and natural nests be concentrated and protected when possible, and that August counts continue for this macaw population.

A workshop to discuss chick protection strategies among local stakeholders was held in May 2004. Active protection of nests, environmental education, stakeholder networking and promotion of economic benefits for locals were the preferred ways to increase the young-to-adult ratios and thus increase the size of the Scarlet Macaw population in Central Pacific Costa Rica (Dear et al. 2004). We will continue our efforts to monitor the population, preserve habitat and work with local people, as recommended by Snyder et al. (1992) and Collar (2000). We believe that it is possible to control poaching pressure when adequate resources are available, and timely, efficient coordination of personnel and anti-poaching efforts is accomplished.

\section{Acknowledgements}

We thank the following volunteers who counted macaws: Jen Anstee, Roy Arroyo, Rafael Arce, Kristen Conway, Guillermo Hernandez, Patrick Herzog, David Lewis, Jill Liske, Leonel Marineros, Mark Myers, Nuran, Mansir Petrides and Arne Stucker. Personnel at Carara National Park provided friendship and support, especially Jorge Gamboa. We are indebted to Hernan Vargas for allowing us to count macaws on his farm, Hacienda Quebrada Bonita. The board of directors of LAPPA have contributed in many ways to developing and carrying out the strategic plan for macaw conservation in the Central Pacific Conservation Area. Finally, the following sponsors made this project possible: The Wildlife Trust, Organization of American States, Club/Hotel Punta Leona, Idea Wild, and the Universidad Nacional of Costa Rica.

\section{References}

Anderson, D. and Burnham, K. (2001) Commentary on models in ecology. Ecol. Soc. of Am. Bull. 82: 160-161. 
Beissinger, S., Brice, A. and Wiley, J. (1994) Recommendations from the APC on scarlet macaw conservation in Costa Rica. Arlington, VA: Association for Parrot Conservation.

Bonadie, W. A. and Bacon, P. R. (2000) Year-round utilisation of fragmented palm swamp forest by Red-bellied macaws (Ara manilata) and Orange-winged parrots (Amazona amazonica) in the Nariva Swamp (Trinidad). Biol. Conserv. 95: 1-5.

Bulmer, M. G. (1974) A statistical analysis of the 10 year cycle in Canada. J. Anim. Ecol. 43: $701-718$.

Chapman, C. A., Chapman, L. J. and Lefebvre, L. (1989) Variability in parrot flock size: possible functions of communal roosts. Condor 91: $842-847$.

Collar, N. J. (2000) Globally threatened parrots: criteria, characteristics and cures. Int. Zool. Yahrb. 37: 21-35.

Collar, N. and Juniper, A. (1992) Dimensions and causes of the parrot conservation crisis. Pp. 1-24 in S. Beissinger and N. Snyder, eds. New world parrots in crisis: solutions from conservation biology. Washington, D.C.: Smithsonian Institution Press.

Damon, T. and Vaughan, C. (1995) Ecotourism and wildlife conservation in Costa Rica: potential for a sustainable partnership. Pp. 211-216 in J. Bissonette and P. Krausman, eds. Integrating people and wildlife for a sustainable future. Washington, D.C.: The Wildlife Society.

Dear, F., Arroyo, R., Arce, A. and Vaughan, C. (2004) Conceptual model of a strategy for Scarlet Macaw (Ara macao) protection in the Central Pacific Conservation Area, Costa Rica. Quebrada Ganado, Costa Rica: Association for Protection of the Psittacines.

Draper, N. and Smith, H. (1998) Applied regression analysis. Third edition. New York: Wiley.

Fallas, J. (1995) Informe sobre la zona de Garabito. Heredia, Costa Rica: Universidad Nacional.

Ferraro, P. and Kramer, R. (1997) Compensation and economic incentives: reducing pressure on protected areas. Pp. 187-211 in R. Kramer, C. Van Schaik and J. Johnson, eds. Last stand: protected areas and the defense of tropical biodiversity. New York: Oxford University Press.

Iñigo-Elías, E. (1996) Ecology and breeding biology of the Scarlet Macaw (Ara macao) in the Usumacinta drainage basin of Mexico and Guatemala. PhD thesis, University of Florida.

La Nación (1995) Alto robo de lapas (28 marzo).

Marineros, L. (1993) La lapa roja (Psittacidae: Ara macao): Ecología, turismo y pautas para su manejo en la Reserva Biológica Carara. Costa Rica. Master's thesis, Universidad Nacional de Costa Rica.

Marineros, L. and Vaughan, C. (1995) Scarlet Macaws of Carara. Pp. 445-467 in J. Abramson, B. Speer and J. Thomsen, eds. The large macaws: their care, breeding and conservation. Fort Bragg, CA: Raintree Publications.

Munn, C. (1992) Macaw biology and ecotourism: or "when a bird in the hand is worth two in the bush". Pp. 47-72 in S. Beissinger and N. Snyder, eds. New World parrots in crisis: solutions from conservation biology. Washington, D.C.: Smithsonian Institution Press.

Myers, M. and Vaughan, C. (2004) Movement and behaviour of scarlet macaws (Ara macao) during the post-fledgling dependence period: implications for in situ versus ex situ management. Biol. Conserv. 118: 411-420.

Nemeth, N. and Vaughan, C. (2004) Feeding observations on Scarlet Macaw (Ara macao) in Costa Rica. Cotinga 21: 71-72.

Renton, K. (2002) Seasonal variation in occurrence of macaws along a rainforest river. J. Field Ornithol. 73: 15-19.

Snyder, N., James, F. and Beissinger, S. (1992) Towards a conservation strategy for Neotropical psittacines. Pp. $257^{-276}$ in S. Beissinger and N. Snyder, eds. New world parrots in crisis: solutions from conservation biology. Washington, D.C.: Smithsonian Institution Press.

Snyder, N., McGown, P., Gilardi, J. and Grajal, A., eds. (2000) Parrots, status survey and conservation action plan 2000-2004. Cambridge, U.K.: International Union for the Conservation of Nature.

Snyder, N., Wiley, J. and Kepler, C. (1987) The parrots of Luquillo: natural history and conservation of the Puerto Rican Parrot. Los Angeles, CA: Western Foundation. 
Stiles, F. and Skutch, A. (1989) A guide to the birds of Costa Rica. Ithaca, NY: Cornell University Press.

Thomsen, J. (1995) Conservation: problems and options in macaw conservation. Pp. 37-383 in J. Abramson, B. Speer and J. Thomsen, eds. The large macaws: their care, breeding and conservation. Fort Bragg, CA: Raintree Publications.

Tosi, J. (1969) Ecological map of Costa Rica. Costa Rica: Tropical Science Center.

Toyne, E. P. and Flanagan, J. N. M. (1997) Observations on the breeding, diet and behaviour of the Red-faced Parrot Hapalopsittaca pyrrhops in southern Ecuador. Bull. B.O.C. 117: $257-263$.

Vaughan, C. (1999) Do local communities in developing countries benefit from ecotourism in national parks and protected areas? Vida Silvestre Neotropical 8: 3-9.

Vaughan, C. (2002) Conservation strategies for a Scarlet Macaw (Ara macao) population in Costa Rica. PhD thesis, University of Wisconsin.

Vaughan, C., Gack, J., Solorzano, H. and Ray, R. (2003a) The effect of environmental education on school children, their parents and community members: a study of intergenerational and intercommunity learning. J. Environ. Educ. 34: 12-21.

Vaughan, C., Nemeth, N. and Marineros, L. (2003b) Ecology and management of natural and artificial Scarlet Macaw (Ara macao) nest cavities in Costa Rica. Ornit. Neotrop. 14: 381-396.

Vaughan, C., Nemeth, N. and Marineros, L. In press. Scarlet Macaw (Ara macao) diet in Central Pacific, Costa Rica. Rev. Biol. Trop.

Wiedenfeld, D. (1994) A new subspecies of Scarlet Macaw (Ara macao) and its status and conservation. Ornit. Neotrop. 5: 99-104.

Wright, T., Toft, C., Enkerlin-Hoeflich, E., Gonzalez-Elizondo, J., Albornoz, M., RodriguezFerraro, A., Rojas-Suarez, F., Sanz, V., Trujillo, A., Beissinger, S., Berovides, V., Galvez, X., Brice, A., Joyner, K., Eberhard, J., Gilardi, J., Koenig, S., Stoleson, S., Martuscelli, P., Meyers, J., Renton, K., Rodriguez, A., Sosa-Asanza, A., Villela, F. and Wiley, J. (2001) Nest poaching in Neotropical parrots. Conserv. Biol. 15: 710-720.

\section{CHRISTOPHER VAUGHAN}

Regional Wildlife Management Program, Universidad Nacional, Heredia, Costa Rica.

Current address: Department of Wildlife Ecology, University of Wisconsin-Madison, Madison, Wisconsin, U.S.A. and Milwaukee Public Museum, Milwaukee, Wisconsin, U.S.A. E-mail: cvaughan@wisc.edu

\section{NICOLE M. NEMETH}

Regional Wildlife Management Program, Universidad Nacional, Heredia, Costa Rica. Current address: Department of Microbiology, Immunology and Pathology, Colorado State University, Fort Collins, Colorado, U.S.A. Email:nnemeth@colostate.edu

JOHN CARY and STANLEY TEMPLE

Department of Wildife Ecology, University of Wisconsin-Madison, Madison, Wisconsin, U.S.A. 